\title{
VIBRATIONS OF AIRCRAFT ENGINES TURBINE BLADES WITH HYSTERETIC ENERGY DISSIPATION
}

Ua Розглядаються коливання лопаток турбін авіаційних двигунів з урахуванням гістерезисного тертя. Нелінійна задача розв'язується за допомогою розкладання за малим параметром. Для визначення власних частот та форм коливань використовується варіаційно-сітковий підхід побудови функціоналів типу Релея та

\footnotetext{
${ }^{1}$ National Technical University of Ukraine "Kyiv Polytechnic Institute"

${ }^{2}$ National Technical University of Ukraine "Kyiv Polytechnic Institute"
} 
мінімізація їх методом покоординатного спуску. Одержані рівняння резонансних кривих лопатки. Задача про вимушені коливання розв'язується шляхом розкладання за власними формами

Ru Рассматриваются колебания лопаток турбин авиационных двигателей с учетом гистерезисного трения. Нелинейная задача решается с помощью разложения по малому параметру. Для определения собственных частот и форм колебаний используется вариационно-сеточный подход построения функционалов типа Рэлея и минимизация их методом покоординатного спуска. Получены уравнения резонансных кривых лопатки. Задача о вынужденных колебаниях решается путем разложения по собственным формам.

\section{Introduction}

Turbines of aircraft gas turbine engines are the main nodes that determine the characteristics of the engine. Compressors and turbines are the bladed machines, elements of which are the blades of the rotor group, called the working blades. The gas stream energy transformation into mechanical energy of the rotor is carried out in the interscapular channels of the turbine wheel. Constructive and technological features of working blades have a fundamental influence on the gas dynamics engine characteristics and stability and reliability of their work. Strength properties of working blades also exert a major influence on the characteristics of reliability, since the breakage of working blades could lead to the destruction of the engine. Considering the hard operating conditions of working blades and their role in the engine, since the reliability and engine resource are usually determined by the reliability and lifetime of the turbine blades, therefore, the task of calculating the blades under the action of vibration loads is important. An interesting approach to study the vibration between shrouded turbine blades in an aero-engine was applied in the work [1]. In deriving the equation of motion the Euler-Bernoulli beam theory was used. The approximate solution of equations was carried out by Galerkin method.

\section{Formulation of the problem}

Let us consider the load on the turbine blades.

Pulsating gas stream acting on the turbine blades can be seen as the overlay of the stream with a speed that changes periodically on stream with constant speed $v$.

Periodic component of the gas stream creates a load distribution along the blade $q(z) \cos p t$ i $m_{z}(\mathrm{z}) \cos p t$, a constant component under blades vibration causes the additional aerodynamic forces which are based on the hypothesis of stationarity [2] and for small angles of attack are expressed as:

$$
\varphi_{1}(z, t)=\frac{\partial C_{y}}{\partial \alpha} \rho b v^{2}\left[\theta+\frac{1}{v} \frac{\partial \theta}{\partial t}\left(\frac{3}{4} b-x_{0}\right)-\frac{1}{v} \frac{\partial y}{\partial t}\right],
$$




$$
\varphi_{2}(z, t)=\frac{\partial C_{m E}}{\partial \alpha} \rho b^{2} v^{2}\left[\theta+\frac{1}{v}\left(\frac{3}{4} b-x_{0}-\frac{\pi b}{16 \frac{\partial C_{m E}}{\partial \alpha}}\right)-\frac{1}{v} \frac{\partial y}{\partial t}\right],
$$

where $\rho$ is the density of gas; $\alpha$ is the angle of attack;

$x_{0}$ is the distance from the front edge to the stiffness center of profile;

$b$ is a chord of profile; $C_{y}$ is a lift coefficient;

$C_{m E}-$ coefficient of lifting force moment as to the torsion axis;

$y$ is a deflection; $\theta$ is a torsion angle.

The scheme of the blade is shown in Fig. 1.

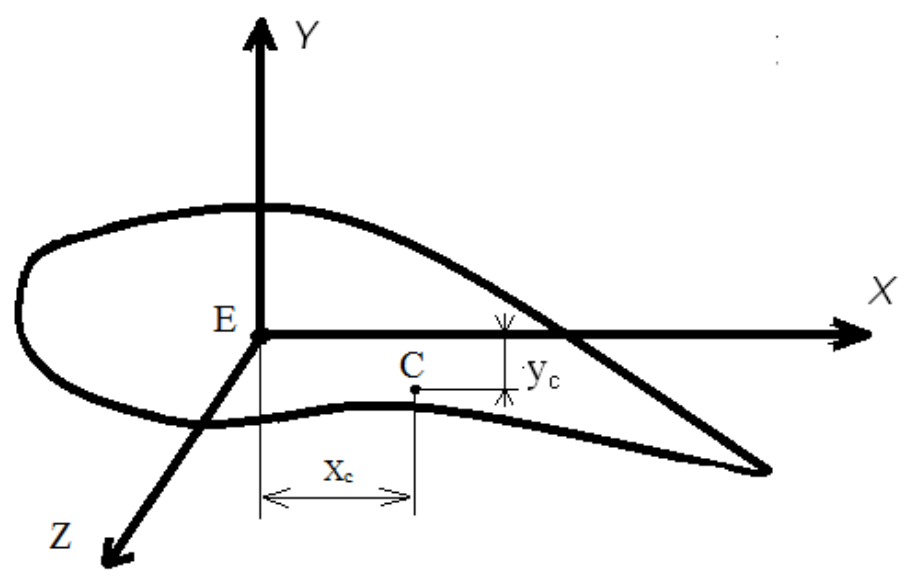

Fig. 1. The scheme of the blade

In view of the gas stream forces and internal energy dissipation, the equation of turbine blade flexion and torsional vibrations in case of rod modes of are look as:

$$
\begin{aligned}
& \frac{\partial^{2}}{\partial z^{2}}\left(E I \frac{\partial^{2} y}{\partial z^{2}}+m \frac{\partial^{2} y}{\partial t^{2}}-m x_{C} \frac{\partial^{2} \theta}{\partial t^{2}}\right)=\varepsilon\left[q(z) \cos p t-f_{1}(z, t)+\varphi_{1}(z, t)\right]- \\
& -\frac{\partial}{\partial z}\left(G I_{d} \frac{\partial \theta}{\partial z}\right)+I_{m} \frac{\partial^{2} \theta}{\partial t^{2}}-m x_{c} \frac{\partial^{2} y}{\partial t^{2}}=\varepsilon\left[m_{z} \cos p t+f_{2}(z, t)+\varphi_{2}(z, t)\right],
\end{aligned}
$$

where $E I$ and $G I_{d}$ are the bending and torsional stiffness of the rod;

$m$ and $I_{m}$ are the inertia moment and mass length unit of the blade;

$x_{C}$ is the distance between the stiffness center and the gravity center of the cross section;

$f_{1}(z, t), f_{2}(z, t)$ are the nonlinear function of energy dissipation in the material during bending and torsional vibrations;

$\varphi_{1}(z, t), \varphi_{1}(z, t)$ are the aerodynamic forces of the gas stream is generally nonlinear, in partial cases may have a linear kind (1).

The forces of internal friction are considerably less than elastic forces and forces of inertia. Aerodynamic forces being proportional to the gas density are 
also smaller than inertia forces of blades. So all the forces on the right side of equation (2) can be considered proportional to the small parameter $\varepsilon$.

To investigate the systems (2) we have applied the asymptotic method of nonlinear mechanics [3], [4]. This method was used by the authors [4] for solutions of rod system bending vibrations with considering energy dissipation. Considering the movement, that describes by system without the right part $(\varepsilon=0)$, as unexcited movement and the forces on the right side are the forcing small forces. The unconstrained system solution $(\varepsilon=0)$ we obtain by a simple way with considering boundary conditions of fixed cantilever rod:

$$
\begin{gathered}
y(0, t)=\theta(0, t)=\frac{\partial y}{\partial z}(0, t)=0, \\
\frac{\partial^{2} y}{\partial z^{2}}(l, t)=\frac{\partial \theta}{\partial z}(l, t)=\frac{\partial^{3} y}{\partial z^{3}}(l, t)=0 .
\end{gathered}
$$

The unconstrained system $(2)$ solution $(\varepsilon \neq 0)$ in the first approximation has the form [3], [4]:

$$
\begin{aligned}
& y(z, t)=a Y(z) \cos (p t+\psi), \\
& \theta(z, t)=a \Phi(z) \cos (p t+\psi),
\end{aligned}
$$

where $Y(z), \Phi(z)$ are the bending and torsional vibrations forms, which were determined from unexcited system $(\varepsilon=0)$;

$\alpha$ is the amplitude coefficient that equal under the terms $Y(1)=1$ to bending oscillation amplitude of the blade free end;

$\psi$ is a phase of oscillation.

The amplitude $\alpha$ and phase $\psi$ are generally determined from the equations of the first approximation (5):

$$
\begin{gathered}
\frac{d a}{d t}=-\frac{x_{2}(a)}{2 \pi M \omega}-\frac{A}{M(\omega+p)} \sin \psi, \\
\frac{d \psi}{d t}=\omega-p-\frac{x_{1}(a)}{2 \pi M a \omega}-\frac{A}{a M(\omega+p)} \cos \psi,
\end{gathered}
$$

and stationary vibrations $\left(\frac{d a}{d t}=0, \frac{d \psi}{d t}=0\right)$ are satisfy the relation (6):

$$
\begin{aligned}
\left(\frac{p}{\omega}\right)^{2}=1-\frac{A}{M \omega^{2} a} & {\left[\cos \psi-\frac{x_{1}(a)}{x_{2}(a)} \sin \psi\right] } \\
\sin \psi & =-\frac{x_{2}(a)}{\pi A} .
\end{aligned}
$$

In equation (5) and (6) the following notation are adopted: 


$$
\begin{gathered}
M=\int_{0}^{l}\left(m Y^{2}+2 m x_{c} Y \Phi+I_{m} \Phi^{2}\right) d z ; \\
A=\int_{0}^{l}\left[\varepsilon q(z) Y(z)+\varepsilon m_{z}(z) \Phi(z)\right] d z ; \\
x_{1}(a)=\int_{0}^{l} \int_{0}^{2 \pi} k_{10}(z, t) \cos (p t+\psi) d(p t+\psi) d z ; \\
x_{2}(a)=\int_{0}^{l} \int_{0}^{2 \pi} k_{10}(z, t) \sin (p t+\psi) d(p t+\psi) d z ; \\
k_{10}(z, t)=\left[\varepsilon f_{0}(z, t)+\varepsilon \varphi_{10}(z, t)\right] Y(z)+\left[\varepsilon f_{20}(z, t)+\varepsilon \varphi_{20}(z, t)\right] \Phi(z) .
\end{gathered}
$$

Aerodynamic forces (1), and expressions for internal friction functions in the first approximation, is taking into account the system decision (4), will equal:

$$
\begin{gathered}
\varphi_{10}(z, t)=\frac{\partial C_{y}}{\partial \alpha} \rho b v^{2} a\left[\Phi \cos \tau-\frac{\Phi}{v} p \sin \tau\left(\frac{3}{4} b-x_{0}\right)+\frac{1}{v} p Y \sin \tau\right] \\
\varphi_{20}(z, t)=\frac{\partial C_{m E}}{\partial \alpha} \rho b^{2} v^{2} a\left[\Phi \cos \tau-\frac{\Phi}{v}\left[\frac{3}{4} b-x_{0}-\frac{\pi b}{16 \frac{\partial C_{m E}}{\partial \alpha}}\right) p \sin \tau+\frac{Y}{v} p \sin \tau\right] \\
f_{10}(z, t)=\mp \frac{v E a^{n}}{n} \iint_{(F)} \xi^{n+1} d F\left[(1 \pm \cos \tau)^{n}-2^{n-1}\right] \frac{d^{2}}{d z^{2}}\left(\frac{d^{2} Y}{d z^{2}}\right)^{n} \\
f_{10}(z, t)=\mp \frac{v E a^{n}}{n} \iint_{(F)} \xi^{n+1} d F\left[(1 \pm \cos \tau)^{n}-2^{n-1}\right] \frac{d^{2}}{d z^{2}}\left(\frac{d^{2} Y}{d z^{2}}\right)^{n} \\
f_{20}(z, t)=\mp \frac{G \eta a^{k}}{k} \iint_{(F)} r^{k+1} d F\left[(1 \pm \cos \tau)^{n}-2^{n-1}\right] \frac{d}{d z}\left(\frac{d \Phi}{d z}\right)^{k}
\end{gathered}
$$

where $n, v$ and $\eta$ are hysteresis loop parameters in accordance with the bending and torsional vibrations;

$\xi$ is a distance from the neutral axis of the cross section to the elementary area $d F$;

$z$ is a distance from the torsion axis to the elementary area $и d F$ of the cross section;

$E$ is the Young's modulus; $G$ is the Shear modulus. 
The process of turbine blade oscillation in the gas stream can be investigated using equations (5).

Resonant oscillation curves of blade are described by equations (6).

For the determination of natural frequencies and blades forms of oscillations the approach, which is based on the variational-grid method of forming finite dimensional functional of Rayleigh type and minimizing it by coordinatewise descent method [5], [6] was used.

For construction of necessary functional the method of increasing stiffness's [5], [6] is proposed. Then, the determination of natural frequencies and mechanical system forms of oscillations comes down to minimization problem:

$$
\omega_{\kappa}^{2}=\inf _{u \in R^{N}} \frac{(\tilde{K} u, u)+c \sum_{k=1}^{l-1}\left(M z_{k}, u\right)}{(M u, u)},
$$

where $(K u, u)$ and $(M u, u)$ are the quadratic forms corresponding to the potential and kinetic energy of the system;

$K$ and $M$ are the matrices of rigidity and mass, respectively,

$u$ is the displacement vector, $z$ is the desired form of vibrations.

From such Rayleigh ratio (22) follows that it's not necessary to build projectors corresponding to founded eigenvectors during calculation process, but is sufficient to store in computer memory only previously defined eigenvectors. This allows to find the spectrum of frequencies and forms with less computational cost in comparison with the traditional approach [5], [6]. After the determination of natural frequencies spectrum and forms of oscillations the problem of forced vibrations of constructions can be solved by decomposition by its own forms of vibrations.

\section{Conclusions}

This paper deals with nonlinear oscillations of elastic gas turbine engines blades with taking into account the hysteresis friction. The problem was solved by the method of decomposition in the small parameter. For the determination of natural frequencies and mechanical systems oscillations forms the variation-grid method of forming Rayleigh type functionals was used and following minimizing it by coordinate-wise descent method. Application of the method of calculation will solve the problem of flexion and torsional vibrations of nonlinear elastic blades as aircraft elements. 


\section{References}

1. Nan, Guofang. Modeling and Dynamic Analysis of Shrouded Turbine Blades in Aero-Engines //JOURNAL OF AEROSPACE ENGINEERING. 2016.-Vol: 29 No: 1. DOI: 10.1061/(ASCE)AS.1943-5525.0000510

2. Иноземцев, A. A. Основы конструирования авиационных двигателей и энергетических установок // А. А. Иноземцев, М. А. Нихамкин, В. Л. Сандрацкий // Т. 4. Динамика и прочность авиационных двигателей и энергетических установок. - М.: Машиностроение, 2008. - 192 с.

3. Василенко, М. В. Теорія коливань і стійкості руху // М. В. Василенко, О. М. Алексейчук /- К.: Вища школа, 2004. - 525 с.

4. Trubachev, S. I. The oscillations of rod constructions with taking into account the energy dissipation /S. I. Trubachev, O. N. Alekseychuk // Механіка гіроскопічних систем №27, -2014, с. 119-124. DOI:http://dx.doi.org/10.20535/0203-377127201438211

5. Бабенко, A. E. Применение и развитие метода покоординатного спуска в задачах определения напряженно-деформированного состояния при статических и вибраионных загрузках // А. Е. Бабенко, Н. И. Бобырь, С. Л. Бойко, О. А. Боронко - К.: Инрес, 2005. - 264 с.

6. Trubachev, S. I. Vibrations of lamellar and rod structures with energy dissipation /S. I. Trubachev, O. N. Alekseychuk // Інформаційні системи, механіка та керування,-№ 14, 2016. - с. 98-105. DOI: http://dx.doi.org/10.20535/2219-380414201678423 